\title{
Language Development or Language Corruption? The Case of Loan-words in Isichazamazwi SesiNdebele*
}

\author{
Cornelias Ncube, African Languages Research Institute, University of \\ Zimbabwe, Harare, Zimbabwe (corneliasbncube@yahoo.co.uk)
}

\begin{abstract}
This article discusses the loan-words in Isichazamazwi SesiNdebele (henceforth ISN), particularly looking at their acceptance and/or non-acceptance by the target users of ISN. In Zimbabwe, Ndebele shares the same linguistic environment with English, Shona and the official minority languages such as Kalanga, Tonga and Nambya. A historical heritage also links it with its Nguni sister languages such as Zulu and Xhosa spoken in South Africa. In selecting headwords for ISN, the Ndebele Lexicographic Unit used the frequency-list method, lemmatising words mostly found in the corpus. This method inevitably allowed the adoption of loan-words in the ISN with resultant public protest. The article is divided into two broad sections. The first section gives a general overview of comments from users of ISN about the inclusion of loan-words in the dictionary. The attitude towards loan-words in the ISN varies with different age groups, the younger generation freely accepting them as part of the Ndebele lexicon as opposed to the older generation. The second section analyses the justification by the editors of ISN for lemmatising loan-words against the views of target users. Reservations against the loan-words in ISN go beyond lexicographic principles. In the forefront is the users' attitude towards the source language. Language attitudes in Zimbabwe are mainly a result of the socio-political and economic power characterising the different tribal or ethnic groups in the country. The article concludes by discussing possible solutions to the problem of loan-words to be adopted in the forthcoming Advanced Ndebele Dictionary.
\end{abstract}

Keywords: LOAN-WORDS, CULTURAL BORROWING, DIALECT BORROWING, LEXICON, ADOPTION, LANGUAGE PURISM, LANGUAGE EMANCIPATION

Opsomming: Taalontwikkeling of taalbederf? Die geval van leenwoorde in Isichazamazwi SesiNdebele. Hierdie artikel bespreek die leenwoorde in Isichazamazwi SesiNdebele (voortaan ISN) deur veral te kyk na hul aanvaarding en/of nieaanvaarding deur die teikengebruikers van ISN. In Zimbabwe deel Ndebele dieselfde taalomgewing met Engels, Sjona en die offisiële minderheidstale soos Kalanga, Tonga en Nambya. 'n Historiese erfenis verbind dit ook met die Ngunisustertale soos Zoeloe en Xhosa wat in Suid-Afrika gepraat word. Vir die keuse van trefwoorde in ISN, het die Ndebele- leksikografiese eenheid die frekwensielysmetode gebruik deur die woorde te lemmatiseer wat die meeste in die korpus aangetref is. Hierdie metode het onver-

* This article was presented as a paper at the Eighth International Conference of the African Association for Lexicography organised by the Department of Germanic and Romance Languages, University of Namibia, Windhoek, Namibia, 7-9 July 2003. 
mydelik die opname van leenwoorde in die ISN toegelaat met die gevolglike openbare protes. Die artikel is in twee breë afdelings verdeel. Die eerste afdeling gee 'n algemene oorsig van die kommentaar van die gebruikers van ISN op die insluiting van leenwoorde in die woordeboek. Die houding teenoor leenwoorde in die ISN wissel by verskillende ouderdomsgroepe, met die jonger geslag wat hulle vrylik as deel van die Ndebeleleksikon aanvaar in teenstelling tot die ouer geslag. Die tweede afdeling ontleed die regverdiging deur die redakteurs van ISN vir die lemmatisering van leenwoorde teenoor die beskouings van die teikengebruikers. Voorbehoude teen die leenwoorde in ISN gaan verder as leksikografiese beginsels. Vooraan is die gebruikers se houding teenoor die brontaal. Taalhoudings in Zimbabwe is hoofsaaklik die gevolg van die sosiopolitieke en ekonomiese sterkte wat die verskillende stam- of etniese groepe in die land kenmerk. Die artikel sluit af met 'n bespreking van moontlike oplossings vir die probleem van leenwoorde wat in die toekomstige Gevorderde Ndebelewoordeboek opgeneem sal word.

Sleutelwoorde: LEENWOORDE, KULTURELE ONTLENING, DIALEKONTLENING, LEKSIKON, OORNAME, TAALPURISME, TAALEMANSIPASIE

\section{Introduction}

The importance of making provision for target users' needs in the compilation of a dictionary has received considerable attention from lexicographers, among others De Schryver and Prinsloo (2000). They argue that feedback from the target users should be carried out simultaneously with the compilation of the dictionary. The process should involve publications of small-scale parallel dictionaries, stimulating feedback, which is eventually fed into the main dictionary. Reference is made here to the indispensability of the 'simultaneous feedback' process because quite often it is bypassed in the dictionary-making process. When it is eventually assessed, De Schryver and Prinsloo correctly assert that such feedback can 'only be implemented in forthcoming editions of these dictionaries'. Although the Ndebele Lexicographic Unit (henceforth NLU) bypassed the process, various lexicographic researches by students at Honours and Masters level had laid important groundwork, which was at the disposal of the editors of the first Ndebele monolingual dictionary, Isichazamazwi SesiNdebele (henceforth ISN), to implement. The research work include those on defining formats by Ndlovu (1998), and entry ordering in Ndebele dictionaries by Maphosa (1997). The problematic area of loan-words in Ndebele received attention from Moyo (1999). Nong et al. (2002) also investigate the problem of loan-words versus indigenous words in Northern Sotho. These researchers concur that the problem with loan-words lies in language attitude which varies from generation to generation. In this article, it is argued that to comprehend the reasons for and/or against loan-words in ISN, it is important to explain both the historical tribal or ethnic relations in Zimbabwe before and after independence, and the socio-political power characterising these different tribal or ethnic groups. The need to contextualise the problem of loan-words in the socio-political milieu of Zimbabwe was realised when the NLU conducted its 
seminar series to invite views on and opinions about ISN. The inclusion of loan-words expectedly generated much interest and debate.

\section{Origins and Sources of Loan-words in Ndebele}

In order to understand the origins of loan-words in the Ndebele language, some information on the historical development and social position of the Ndebele community is needed. The Ndebele speech community is a mixture of the Ndebele, Kalanga, Xhosa, Sotho, Venda and Nambya tribal groups. During the precolonial period, the different ethnic groups had a hierarchical coexistence. At the zenith of the social scale was the royal family (Khumalos and those of Nguni descent). This group was called abeZansi, a designation that reflects its prestigious status in the earlier Ndebele community. The Xhosa and the Sotho, originally from South Africa, as well as those incorporated into the Ndebele state in the previous Transvaal area, were perceived as part of the mainstream Ndebele ethnic group. In terms of social status, the group called abeNhla ranked second after the royal class. Following their defeat, the Kalanga, Tonga, and Nambya groups were incorporated into the larger Ndebele group when it settled in present-day Zimbabwe. Adjacent to this amalgamated Ndebele speech community was an equally large Shona ethnic group over which the Ndebele had jurisdiction. The Shona, Kalanga, Tonga and Nambya groups were derogatively called amaHole. The relevance of these labels shall be referred to in detail in section 3.2

The historical heritage linking the Ndebele language to its Nguni sister language Zulu was conserved and maintained throughout the above hierarchical social arrangement and later through the education policy which allowed the introduction of Zulu literature in the school and college syllabi. Each ethnic group in the region, however, continued to speak its native language, albeit increasingly adopting the language of the conqueror, the Ndebele. Emerging as the language of the privileged in the region, Ndebele has been forced to develop in a multilingual environment composed of Kalanga, Xhosa, Sotho, Tonga, Nambya, Venda and later, on a national level, Shona and English. The above scenario inevitably resulted in both cultural and dialectal borrowing between languages. It is a generally accepted and undisputed opinion and observation that where cultural exchange and dialectal code switching are involved, lexical borrowing simultaneously takes place. In tracing the origins of loan-words in Ndebele, Zulu is certainly the primary source. In fact, Zulu continues to facilitate the entrance of loan-words from other languages into the Ndebele lexicon. A historical inquiry of the origins of many words that today are assumed, superficially, to be authentic Ndebele words, shows either English or Afrikaans as the source languages. Hadebe (2000: 229) notes:

Ndebele has adopted more terms from English and Afrikaans than from a combined sum of all the several African languages in daily contact with the Ndebele people. 
This observation shows the underlying attitude associated with the source language(s) of loan-words. This point will be discussed in detail under section 3.2. The table below shows examples of words whose source can be traced to either English or Afrikaans:

\begin{tabular}{|l|l|l|l|}
\hline ENGLISH & AFRIKAANS & ZULU & NDEBELE \\
\hline table & tafel & itafula & ithebuli / itafula \\
\hline pills & pille & amaphilisi & amaphilisi \\
\hline window & venster & ifasitele & iwindo / ifasiteli \\
\hline store & winkel & ivinkili & isitolo / ivinkili \\
\hline
\end{tabular}

Most of these loan-words, which today have been naturalised as authentic Ndebele words convey ideas, concepts and/or objects previously unknown to or inexpressible in Ndebele (or Zulu itself). Because certain loan-words had not yet entered Zulu, borrowing sometimes took place directly from other languages such as English, instead of indirectly by the adoption of the rephonolised Zulu form. Thus words like ireza (razor) and idotibhokisi or ibhini (dustbin) now appear as part of the Ndebele lexicon, but the Zulu variants (cf. Doke et al. 1990) such as impuco, ingego or incoshoba and ibhokisi lezibi (likadoti) respectively have not been borrowed. The other variant insingo, though appearing in both Zulu and Ndebele, no longer belongs to the active lexicon of Ndebele. The phrase ibhokisi lezibi appears in everyday spoken Ndebele, but has not been entered as a lemma in ISN. This signals a shift from taking every adoption from Zulu as authentic and therefore correct. In resorting to coining as another source of words, the editors seem to have heeded the warning of Moyo (1999: 32) that selecting lexical entries simply because they are found in Zulu paints 'a rather negative picture ... about Ndebele because Ndebele will be presented as being inferior to Zulu'.

It has also proved difficult for Ndebele (like all languages) to become an 'isolated language' in a multilingual society like that characterising Zimbabwe. As can be expected, from a linguist's point of view, Ndebele has enriched its vocabulary by borrowing words like inopi (pumpkin porridge) and ishamari (a person involved in an illicit love affair) from Kalanga and Shona respectively. Using the frequency-list method, editors of ISN selected and lemmatised headwords found in the Ndebele corpus. The lemma carrying the definition is that most frequently used in the corpus. But, as Kennedy (1998: 34) observes, 'it is easy to overestimate the probability of occurrence of the low frequency words of a language', because frequency depends on whether real life contexts where the words are generally used were ever mentioned during interviewing. The method nonetheless presented the possibility for the inclusion of loan-words in the dictionary. Does the inclusion of such loan-words imply that ISN adds linguistic evidence of a developing language? Or does ISN provide lexicographers (and general language practitioners) with a case-study of a language corrupted in the name of academic correctness? 


\section{Language Development or Language Corruption?}

\subsection{Loan-words and attitude: the target users' perspective}

The inclusion of loan-words in a dictionary generates much interest from the mother-tongue speakers of a language. The mother-tongue speakers of Ndebele are generally concerned with the written and relatively less with the spoken form of the language. Thus second language speakers of Ndebele are 'unconsciously' spared the criticism of mispronunciation and even distorting the syntactic features of Ndebele in spoken form. When it comes to the written form of Ndebele, both first and second language speakers are expected to correctly record the language. A person is judged to have a good command of written Ndebele, if he/she uses the words perceived as original to the language.

It is against this background that the editors of ISN were criticised for lemmatising loan-words. The argument is that if lexicographic activities at ALRI are aimed at promoting the use and at the same time preserving of the indigenous languages, then Ndebele should be recorded and included in its earlier state. Ascertaining the earlier composition of a language's authentic lexicon, however, is a daring task for a lexicographer to undertake. The biggest challenge is to circumscribe a point in history when a language like Ndebele, for instance, existed as an 'isolated language', unadulterated by loan-words. Words today perceived as original to Ndebele were once also new and probably also caused controversy, as is the case with newly adopted loan-words. This points to the difficulty of determining the number of loan-words in Ndebele. As can be expected, however, the target users of ISN complained that too much borrowing could corrupt 'their' language. The inclusion of words having the sounds /r/ and /dzw/ was thus criticised by most mother-tongue speakers of Ndebele. The general feeling was that editors should not have included loan-words in ISN, especially where Ndebele has equivalent terms. The following examples can be noted:

\begin{tabular}{|l|l|l|}
\hline NDEBELE & LOAN WORD & SOURCE LANGUAGE \\
\hline isijeza & inopi & Kalanga \\
\hline ukuhlukuluza/ukuhlupha & ukudzwinyisa & Kalanga \\
\hline umbangazwe & ipolitiki & English \\
\hline ubabhemi & idonki & English \\
\hline ishende & ishamari & Shona \\
\hline
\end{tabular}

This list represents a sample of loan-words considered unnecessary and hence should have been excluded since most of them have equivalents original to Ndebele. These favoured words, however, are not actively used in everyday conversation. This reinforces the point that those who directly experience the borrowing and are themselves the borrowers object to the standardization of these same borrowed words. The objections came despite the research team 
having explained how the collection of words was carried out. This was accomplished through a rigorous process of recording everyday conversations from different Ndebele communities scattered throughout the Matebeleland and Midlands provinces, in this way creating a corpus that was used as basis for compiling the dictionary. The dictionary, it was argued, is a reflection of how the Ndebele speak the language at present. This argument was objected to on the grounds that Ndebele's status was being corrupted and that ALRI was furthering the corruption by large-scale borrowing without 'separating the chaff from the grain', as one observer complained. It is within this context that creativity is called upon in coining 'better' words in place of such terms as ifayinifesi (fine face) and ikheshithokhu (cash talk).

It should be noted, however, that the non-acceptability of the $/ \mathrm{r} /$ sound is not consistent in all instances where it occurs in loan-words. For example, some users of ISN are comfortable to accept the $/ \mathrm{r} /$ sound in words such as irula (ruler) and irobhothi (robot), but are not comfortable when the same sound appears in words such as ishamari. It is apparent that some words are denied a place in the Ndebele lexicon according to the attitude towards the source language. For instance, words such as inopi and ishamari were criticized because they are borrowed from Kalanga and Shona respectively. A suggestion was made that for ishamari the editors should have borrowed its Zulu equivalent ishende. Similarly, others argued that the word ukudzwinyisa (bullying) is the slang form of ukuhlukuluza/ukuhlupha which are the formal Ndebele equivalents. Objections against the inclusion of $u k u d z w i n y i s a$ are motivated by the fact that the sound /dzw/ is not found in Ndebele and the word itself is borrowed from Kalanga.

It is clear that the contention about the loan-words included in ISN is the attitude towards the source language and not the concept of borrowing itself.

\subsection{Factors determining the users' attitude towards loan-words in ISN}

Sebba (1997: 4) stresses:

Almost as obstinate and damaging an idea is the notion that languages can be, and should be, 'pure'.

Language attitude generally reflects ideological/cultural contradictions amongst different ethnic groups. Mparutsa et al. (1992: 237) argue that these contradictions are 'motivated by different socio-economic interests'. In Zimbabwe, the root cause of these contradictions, which inevitably foster language attitude dates back to the historical ethnic/tribal relations before and after the country's independence.

In section 2, it has been noted that during the precolonial era, the Ndebele community was socially divisive. An association with the royal family (abeZansi) of the Ndebele state bestowed high and prestigious social status on an individual. As a result, the Ndebele language ended up reflecting the divisions in 
the society. Herbert (1992: 5) notes that the potentiality of a language to be socially divisive 'is readily observable in the words that have been used to label population groups'. It is also a generally acceptable view that the power to name derives from social dominance which is true of the precolonial Ndebele speech community. Consequently, the language of the privileged was regarded as the language of officialdom. The lingua-franca status of the Ndebele language was further reinforced by the colonialists, who made it a policy that Ndebele had to be taught in place of the region's indigenous languages such as Kalanga and Nambya. In Bulilimamangwe, Kalanga chiefs were even replaced by Ndebele chiefs, in line with the dominance of the Ndebele language. The effects of these changes are today reflected in language attitude. Although Ndebele and the region's local languages continue to be in a close diglossic relationship, the stereotypical language status created before independence still continues. To date, minority groups such as the Kalanga favour Ndebele in place of their mother tongues. In such a situation, borrowing is conceived of as an anomaly when it occurs from a perceived language of 'low status' to a perceived language of 'high status'. McMahon (1994: 202) concurs:

In cases of close contact two languages may not be perceived as equivalent in status within their speech communities ... In such linguistic relationships of unequal prestige borrowings generally move from the more to the less prestigious language.

Accordingly, Ndebele mother-tongue speakers find it difficult to accept Kalanga words such as inopi (pumpkin porridge) and isiki (syphilis) in ISN, even though the corpus reveals that these words are also active in strictly Ndebelespeaking areas. The original Ndebele words, isijeza and ingulamakhwa respectively, are becoming obsolete. After the country's independence, Shona and Ndebele were declared national languages while English continued as the 'de facto language of power and economic advancement' (Mparutsa et al. 1992: 238). The shift in policy was recommendable as it acted as the liberation's counterideology, which Mparutsa et al. (1992: 238) argue put 'emphasis on the pride of indigenous culture and language' in order to fight the colonial ideological hegemony. However, the political instability that emerged soon after independence between the country's major political parties of (PF) ZAPU and ZANU $(\mathrm{PF})$, consciously or unconsciously, triggered a rise in the levels of contradictions existing between language usage and language attitude in present-day Zimbabwe. The two national languages, Ndebele and Shona, thus emerged out of the political conflict with their own linguistic struggle - a struggle for purism. It is against this background that it should be understood why the $/ \mathrm{r} /$ sound in a word such as ishamari is denied its place in the Ndebele lexicon while it is accepted in a word such as irula. A similar degree of reluctance to accept the /1/ sound even in words Shona borrowed from Ndebele has been observed among Shona speakers.

Age is also an important factor in users' attitude towards the inclusion of loan-words in ISN. Nong et al. (2002: 17) observe that 'younger respondents 
seem to accept loan-words much more easily than the older generation'. Resistance to loan-words by the older generation should be understood within the context of the high social status Ndebele (abeZansi) had over other ethnic groups during the precolonial period. It is subsequently a result of the perceived prestigious linguistic status of Ndebele over the regional languages such as Kalanga, Tongo, Nambya and Sotho. Add to this the post-independence political conflict, which apparently took tribal dimensions, and it becomes clear why the older generation who lived through the experience rejects any influence from Shona. However, the conservatives propagating a pure Ndebele language, suppress the political causality by arguing for 'language emancipation' from Shona and English. Tribal causality is also suppressed by arguing for 'language purism' free from corruption by minority languages such as Kalanga, Tonga, Nambya and Sotho. Instead, 'tradition' is used to justify the demand for the 'pure' state of Ndebele, the merits of which arguably lie in its preciseness, musicality, logicality, lyricism etc. Sebba (1997: 4), however, notes that purist attitudes 'are cultural phenomena which can, and do, change with time and which are not invariant from generation to generation or society to society'. The younger generation, who only has a remote recollection of the high status of the Ndebele language and a hazy politically informed comprehension of the linguistic struggle in Zimbabwe, has a moderated attitude towards loan-words. Their attitude is conditionally determined by the problems loan-words pose in the education curriculum. Otherwise, the younger generation, in particular those of school-going age, is favourably inclined towards the inclusion of loanwords in ISN. The dilemma of the younger generation is whether to proceed and use the loan-words notwithstanding the strong resistance by teachers who, for instance, prefer the original words umkambo (flea market) and esilindweni (bus stop) instead of the commonly used ifilimakhethi and ibhasitopu respectively. A student/pupil who uses the controversial loan-words risk being evaluated as and penalized for lacking a good command of Ndebele.

The problem reveals the insufficient liasing between Zimbabwe's main examination regulating board, ZIMSEC (Zimbabwe Schools Examination Council) and the lexicographic activities at ALRI (including other language research departments at the University of Zimbabwe). New developments in the structure of a language are first and foremost noticed by lexicographers and linguists in general. With a view to this, it would be expected of the Ministry of Education and ZIMSEC to work closely with academics at universities when designing school syllabi and setting examinations. The young generation agrees that ISN has been useful as far as Ndebele grammar is concerned. Attention should now be directed towards ensuring that the language as reflected in ISN becomes acceptable in examinations. At this point, a close working relationship between ALRI and the Ministry of Education, Sports and Culture, under whose auspices ZIMSEC falls should be fostered as a matter of urgency. One of the functions of a dictionary is to popularize newly introduced words. It is apparent, however, that in as much as the editors of ISN want to popularize loan-words, this might not succeed unless the words are acceptable in exami- 
nations in both teachers' colleges and schools. There is a big chance that loanwords such as ishamari which are actively used today may not stand the test of time. The reason for this is that some words are introduced into the lexicon of a language for the sake of style. The lexicographer therefore has the difficult task of distinguishing between loan-words used colloquially and those used formally in written or spoken form. Failure to distinguish between colloquial and formal words seems therefore to be one of the factors influencing the negative attitude towards loan-words. This shows that popularization through lexicography alone is not enough, especially where a dictionary culture amongst the general users is, as observed by Maphosa (1997), very low.

\subsection{Loan-words and corpus-based lexicography: the editors' perspective}

In a multilingual society such as the one characteristic of Zimbabwe where the language attitude is very much pronounced, it is imperative for the lexicographer to authenticate or justify his/her dictionary entries so as to avert criticism for lemmatizing controversial loan-words. Authentication or justification in ISN is found as part of the front matter and in some instances sentences retrieved from the corpus for purposes of clarifying definitions. In the front matter, the editors explicitly state that the corpus was the basis for the selection of headwords for lemmatization. From a lexicographic point of view, synchronic attestation by the speech community is accountable for the increase in loanwords in Ndebele. This sheds light on the merits of corpus-based lexicography. Landau (1984: 280) accentuates the advantage of using a corpus for lexicography:

One enduring value of such a computer-generated file for lexicography is, theoretically, to provide a solid basis for reexamining the definitions of the standard lexicon. It can also be a treasure of information on word frequency, punctuation, preferred written form (spelling, capitalization, and compounding), word order, verb patterns, and other grammatical data.

A corpus, therefore, is a useful tool to which generalisations and hypotheses on the language can be referred for verification. From the editors' point of view, the inclusion of loan-words in ISN is justified. Instances where perceived 'original' Ndebele words like, for example, umkambo and umlola (vs isepa (English soap)) appear in the corpus, they have a probability usage of $15 \%$. The usage of the original words was mostly taken from older literature or from interviews involving older people. Loan-words, on the other hand, are found in interviews involving both the older and younger generations. The probability usage of loan-words represents $85 \%$ of the total Ndebele lexicon. The increasing use of loan-words reflects that Ndebele 'is adapting to the dynamic world's technological and scientific innovations' (Moyo 1999: 42). The inclusion of loan-words from Kalanga and Shona such as inopi and ishamari is not aimed at corrupting the purity of Ndebele. Instead, from a lexicographic viewpoint, ISN is synony- 
mous with culture speaking to its people. What the dictionary is saying to the people is that their cultural values have undergone a cycle of transformation. The dictionary captures signs of slight changes in attitudes towards other languages. These changes are today reflected in the loan-words in Ndebele.

\section{Possible Solutions}

Moyo (1999: 42) argues that the problem with loan-words in Ndebele can be solved by a change in 'the social attitudes the Ndebele people have with regards to language'. Moyo further argues that the Ndebele's acceptance of the universal principle that language changes will make the inclusion of loanwords 'an acceptable move characteristic of all languages'. Although the importance of a change in language attitude may be seen as one of the possible solutions, additional ways of authenticating the Ndebele lexicon can be proposed.

The present authentication as it appears in the front matter is inadequate for laypersons or general users who rarely consult it. In its present form, the ISN assumes selfauthentication of loan-words. It is for this reason that additional information about the lemma is proposed for inclusion in the Advanced Ndebele Dictionary (AND). Consequently, editors of AND consider the inclusion of the etymology of controversial loan-words as a solution. The etymological field, it must be noted, might perhaps be helpful to a language specialist such as a lexicographer or linguist, but hardly to the layperson or general user. A language specialist has both a practical and a theoretical interest in the language. A layperson or general user, on the contrary, is solely practically concerned with definitions and the conservative form of the language. To a language specialist therefore, AND can become a source for both the diachronic and synchronic study of Ndebele and for comparative studies regarding the stability of varieties and the general nature and direction of change in Ndebele. For the layperson or general user to know the source language from which the loan-lemma had been borrowed could be sufficient.

The inclusion of etymology therefore will not necessarily entail a change of attitude towards the source language from which the borrowing took place. Because a negative attitude towards the source language can mirror the same attitude towards the speakers of that language, it will probably take a political rather than a linguistic solution to resolve this. The acceptance of loan-words and the attitude towards the source language of the loan-words will always overlap in the view of the layperson. For purposes of the acceptance of loanwords, it might help to bridge the gap between the lexicographic activities at ALRI and ZIMSEC. There is an urgent need for the Ministry of Education, Sport and Culture to formulate a policy that recognizes the loan-words in ISN as acceptable in examinations. At present, the incorporation of loan-words into the Ndebele lexicon is prevented by the examiner by penalizing students using them. It might also be helpful to introduce a lexicography course in teachers' colleges since classroom practitioners are the very people who teach the lan- 
guage. This will go a long way in helping them appreciate the science of language change and language development.

\section{Conclusion}

This article has shown that Ndebele develops in a multilingual environment. The increasing adoption of loan-words can be accounted for by taking into consideration the diglossic environment in which Ndebele develops. Despite the increasing use of loan-words by the speakers in everyday speech, their inclusion in ISN has been viewed as a process of 'language corruption'. There are, however, some inconsistencies, with some loan-words with the same problematic sounds apparently being accepted but others being denied a place in the Ndebele lexicon. In instances where loan-words are resisted, this article has shown that the aspect of language attitude is at play and not the principle of borrowing itself. The deep-rooted problem of language attitude among the speakers of Ndebele can be explained by taking into consideration the 'divisive' nature of the Ndebele community in precolonial Zimbabwe. It also emanates from the political conflict, which took a tribal bias soon after independence. The younger generation, however, appreciates the inclusion of loan-words, with the only problem lying in the gap between lexicography and the education curricula in Zimbabwe. Bridging this gap is seen as a positive step towards ensuring the acceptability of these loan-words in examinations. From a lexicographic point of view, loan-words vindicate the widely accepted opinion that there is no static language. Every language grows, Ndebele being no exception to the rule. As a step forward, the inclusion of etymology is proposed for the Advanced Ndebele Dictionary, although it might benefit the language specialist more than the layperson or general user.

\section{References}

De Schryver, G.-M. and D.J. Prinsloo. 2000. The Concept of 'Simultaneous Feedback': Towards a New Methodology for Compiling Dictionaries. Lexikos 10: 1-31.

Doke, C.M. et al. 1990. English-Zulu/Zulu-English Dictionary. Johannesburg: Witwatersrand University Press.

Hadebe, S. 2000. Developing Terminology in African Languages with Special Reference to Ndebele. Chiwome, E.M. et al. (Eds.). 2000. Indigenous Knowledge and Technology in African and Diasporan Communities: Multi-disciplinary Approaches: 225-231. Harare: Mond Publishers.

Hadebe, S. et al. (Eds.). 2001. Isichazamazwi SesiNdebele. Harare: College Press.

Herbert, R.K. (Ed). 1992. Language and Society in Africa: The Theory and Practice of Sociolinguistics. Johannesburg: Witwatersrand University Press.

Kennedy, G. 1998. An Introduction to Corpus Linguistics. London: Longman.

Landau, S.I. 1984. Dictionaries: The Art and Craft of Lexicography. London: Cambridge University Press. 
Maphosa, M. 1997. The Morphological Structure of the Noun in Ndebele and its Implications on the Ordering of Entries in Ndebele Dictionaries. Unpublished B.A. Hons. Thesis. Harare: University of Zimbabwe.

McMahon, M.S. 1994. Understanding Language Change. Cambridge: Cambridge University Press.

Moyo, P. 1999. Headword Selection for the General Ndebele Dictionary: Problems and Probable Solutions. Unpublished B.A. Hons. Thesis. Harare: University of Zimbabwe.

Mparutsa, C. et al. 1992. An Initial Investigation into Language Attitudes of Secondary School Students in Zimbabwe. Herbert, R.K. (Ed.). 1992. Language and Society in Africa: The Theory and Practice of Sociolinguistics: 235-245. Johannesburg: Witwatersrand University Press.

Ndlovu, F. 1998. Considering Factors that are Relevant to Adopting and Adapting COBUILD Defining Formats for the General Ndebele Dictionary. Unpublished M.A. Thesis. Harare: University of Zimbabwe.

Nong, S. et al. 2002. Loan-words versus Indigenous Words in Northern Sotho: A Lexicographic Perspective. Lexikos $12: 1-12$.

Prinsloo, D.J. et al. 2000. The Dictionary-Making Process with 'Simultaneous Feedback' from the Target Users to the Compilers. Paper presented at the Fifth International Conference of the African Association for Lexicography at the University of Stellenbosch, Stellenbosch, 3-5 July 2000.

Sebba, M. 1997. Contact Languages: Pidgins and Creoles. London: Macmillan Press. 